\title{
DESERTIFICATION IN EUROPE
}


Proceedings of the Information Symposium in the EEC Programme on Climatology, held in Mytilene, Greece, 15-18 April 1984,

under the sponsorship of the Commission of the European Communities

Directorate-General for Science, Research and Development

\section{UNESCO/MAB}

University of Thessaloniki

Governmental and Local Hellenic Authorities

Publication arrangements

\section{P. P. ROTONDO}

Commission of the European Communities

Directorate-General Information Market and Innovation 
Commission of the European Communities
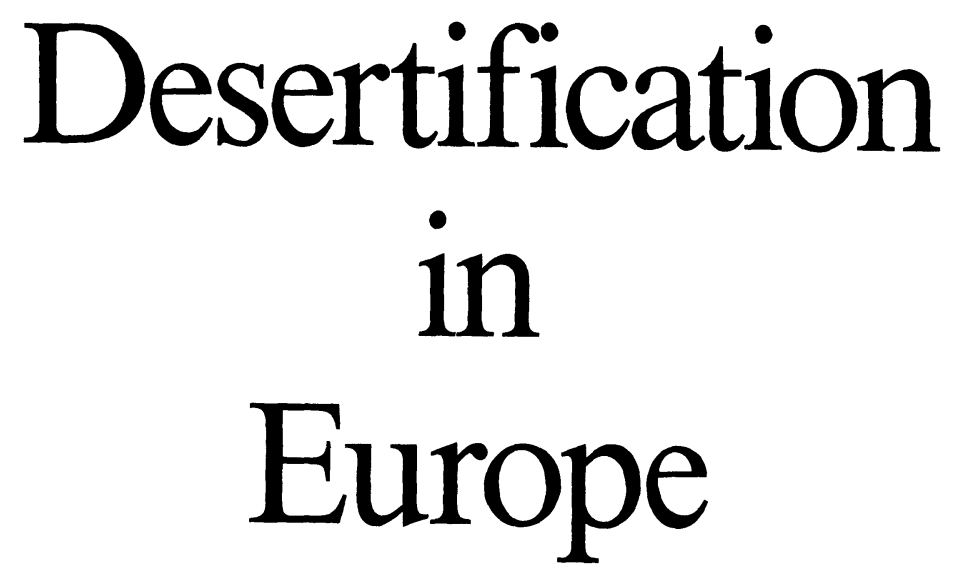

Proceedings of the Information Symposium in the EEC Programme on Climatology, held in Mytilene, Greece, 15-18 April 1984

\title{
Edited by
}

\section{R. FANTECHI}

Commission of the European Communities,

Directorate-General for Science, Research and Development, Brussels, Belgium

and

\author{
N. S. MARGARIS \\ University of Thessaloniki, Division of Ecology, \\ Department of Biology, School of Sciences, Thessaloniki, Greece
}




\section{Library of Congress Cataloging in Publication Data}

Information Symposium in the EEC Programme on Climatology (1984: Mytiléné, Lesbos Island, Greece)

Desertification in Europe.

At head of title: Commission of the European Communities.

Includes index.

1. Desertification-Europe-Congresses. 2. Desert soils-Europe-Congresses. I. Fantechi, Roberto, II. Margaris, N. S. III. Commission of the European Communities. IV. Title.

GB648.42.154 $1984 \quad 551.4 \quad 86-3290$

ISBN 978-94-010-8565-6 ISBN 978-94-009-4648-4 (eBook)

DOI 10.1007/978-94-009-4648-4

Publication arrangements by

Commission of the European Communities

Directorate-General Information Market and Innovation, Luxembourg

EUR 10395

๑ 1986 Springer Science+Business Media Dordrecht

Originally published by ECSC, EEC, EAEC, Brussels and Luxembourg 1986

Softcover reprint of the hardcover 1st edition 1986

LEGAL NOTICE

Neither the Commission of the European Communities nor any person acting on behalf of the Commission is responsible for the use which might be made of the following information.

\footnotetext{
All Rights Reserved

No part of the material protected by this copyright notice may be reproduced or utilized in any form or by any means, electronic or mechanical, including photocopying, recording or by any information storage and retrieval system, without written permission from the copyright owner.
} 
Despite the fact that spain already finds itself on the UNO map of desertification, when mentioning the subject of desertification in Europe the most usual reaction is well that embodied in the title of Prof. Mensching's paper: "Desertification in Europe ?", and according to the various interlocutors the question mark may express any nuance from candid astonishment to perplexity and beyond. Most of the problem concerning the acceptance of the concept of "Desertification in Europe" is semantic in character. "Desert" as a place where sand dunes roam about with hardly any vegetation and no water is the mental picture one generally gets. Yet "desertification" is no desert: it is, as the suffix-ication clearly indicates, a process, of which a full desert is one end, a healthy ecosystem being the other. It is a degradation process which deserves being studied in any of its phases because of the dangers involved. When the cost of the restoration of a land to its former productivity is higher than whatever net gain may have been obtained at the price of the decrease in productivity, one has to acknowledge that some precious resources have been lost, irrespective of the fact that rain may fall and certain plants still grow. Something has to be abandoned, deserted, and that is desertification.

The definition of "desertification" has been the object of many discussions. Normally, and quite understandably, the various definitions found in the literature reflect more their authors' concern and scientific interest rather than an inquiry into the actual meaning of the word itself. We would venture to suggest that Rapp's definition ("the spread of desert-like conditions in arid and semi-arid areas up to $600 \mathrm{~mm}$, due to man's influence or to climatic change") is the one which best fits the concept we are discussing. The rainfall limit set by Rapp is easily seen to include most of Southern Europe. The human component is the key to the observed difference in conditions between, say, Greece and sahel. The climatic component is a warning that man's activities may in the end be unable to avoid passing the point beyond which the process is no longer reversible.

The papers collected in this book provide evidence that the continuous loss of fertile soil is a constant in at least the Mediterranean Europe. The problem is not new. As the symposium on European Desertification took place jn Greece, it is becoming to evoke that greatest among men, Plato . In Critias, 111, b-d, he gives a picture of ancient Attica. He says that "many and remarkable floods have occurred ..... The mass of soil which descended steeply from high places did not expand, as it does elsewhere, in terraces, and its great flow rolling down unceasingly was finally lost in the deep. Since then what remains, as one can see it in small islands, offers, when comparing the present conditions to those then prevailing, the image of a body that a sickness has made skeletal, once all that I owe to A.T. Grove that my attention has been brought upon this passage of $P$ lato. 
which earth has of fat and soft has left the bones, only the fleshless body of the land remaining". Plato goes on recalling the time when the country "had vast forests on its mountains... which today only have what can nourish bees ... The land was carrying abundant pastures for cattle. Moreover, .... the water which every year fell from sky to fecundate them, was not lost by the soil as it is today and did not leave the bare ground to flow down into the sea; on the contrary the soil had plenty of it and stored it in its bosom and kept it under a mantle of clay. Then water, descending from high places, ... provided everywhere an inexhaustible flow to fountains and rivers".

Here is a precise account of both climatic and anthropogenic factors of land degradation, as we say nowadays. A climate change can also be inferred from Plato's description, and one may argue whether man has had a part in it.

Today, man's role in environmental degradation is increasing in importance. As A.T. Grove points out, we have to face accelerated erosion and sedimentation, soil salinization, falling water-tables, further deterioration of the plant cover and urban sprawl, processes which, even though they operate locally, have nevertheless a community-wide dimension. If one views all those processes in the frame of a semi-arid climate, and if one is willing to consider the possibility of a man-induced climate change in a short or medium term, due to increasing atmospheric $\mathrm{CO}_{2}$, the need for a lucid awareness of dangers and opportunities, such as sound, applied research can provide, is only too obvious.

It is therefore with satisfaction that the editors acknowledge the support and encouragement received from Dr. Ph. Bourdeau, Director, Environment, Raw Materials and Materials Technologies Research Programmes (DG XII), Commission of the European Communities, Brussels. 


\section{A. DESERTIFICATION : FACTORS AND PROCESSES}

Desertification in Europe? A critical comment with examples from Mediterranean Europe

H.G. MENSCHING

The scale factor in relation to the processes involved in "Desertification" in Europe

A.T. GROVE

Desertification in a changing climate with a particular attention to the Mediterranean countries

A. BERGER

The effects of model-generated climatic changes due to a $\mathrm{CO}_{2}$ doubling on desertification processes in the Mediterranean area

H.J. JUNG, ๗. BACH

Landscape changes in Greece as a result of changing climate during the quaternary

\section{R. PAEPE}

Comparison of climatic evolution during post-glacial times in Greece, tropical and subtropical regions, in relation to desertification

E. VAN OVERLOOP

Climatic implications of glacier fluctuations

J.M. GROVE

\section{B. FACING DESERTIFICATION : CRITERIA, METHODS AND PROGRAMIES}

Productivity, variability and sustainability as criteria of desertification 
A new integrative methodology for desertification studies based on magnetic and short-lived radioisotope measurements

F. OLDFIELD, S.R. HIGGITT, B.A. MAHER, P.G. APPLEBY,

M. SCOULLOS

An eco-geomorphological approach to the soil degradation and erosion problem

A.C. IMESON

Hazard mapping as a tool for landslide prevention in Mediterranean areas

Th. W.J. VAN ASCH

The "Lucdeme" program in the Southeast of spain to combat desertification in the Mediterranean region

A. PEREZ-SOBA, F. BARRIENTOS

Soil conservation problems in Italy after the Council of Research finalized project

F. MANCINI

\section{SOME CASE STUDIES}

Desertification in Northwestern Greece; the case of Kella

D. VOKOU, J. DIAMANTOPOULOS, Th. A. MARDIRIS, N.S. MARGARIS

The mining factor in the desertification process

I. ROUSSIS, D. VOKOU, Th. A. MARDIRIS, N.S. MARGARIS

Desertification due to air pollution in Attica

N.S. MARGARIS, M. ARIANOUTSOU-FARAGGITAKI, S.TSELLAS,

L. LOUKAS

Minimization of photosynthesis due to air pollution

G. PSARAS, M. ARIANOUTSOU-FARAGGITAKI, N.S. MARGARIS

The Central Huerva Valley (Zaragoza, Spain) : A part of Sahara in Europe

J. DIAMANTOPOULOS

Soil erosion and land degradation in Southern Italy

H.M. RENDELLL

Aspects of desertification in Sardinia - Italy

A. ARU

Desertification through acidification : the case of Waldsterben

w. BACH

Soil degradation in a North European Region

J.T. MØLLER 